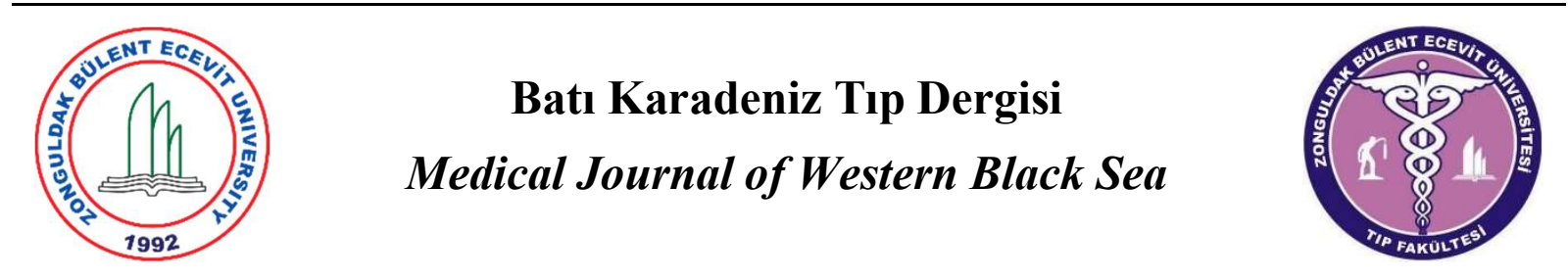

Araştırma Makalesi

Doi: 10.29058/mjwbs.2019.2.2

\title{
Vasküler Demans Modelinde Çevresel Zenginleştirmenin Depresyon Benzeri Davranış, Kortikal ve Hipokampal BDNF ve IL-1 $\beta$ Seviyeleri Üzerine Etkisi
}

\section{Osman Cengıl a, Hale Sayan Ozacmak ${ }^{\mathrm{b}}$, Inc1 Turan ${ }^{\mathrm{b}}, \mathrm{V}$. Haktan Ozacmak ${ }^{\mathrm{b}}$}

${ }^{a}$ Zonguldak Bülent Ecevit Üniversitesi Sağlık Bilimleri Enstitüsü Fizyoloji Anabilim Dalı, Zonguldak, Türkiye.

${ }^{b}$ Zonguldak Bülent Ecevit Üniversitesi, Tıp Fakültesi Fizyoloji Anabilim Dalı, Zonguldak, Türkiye.

ORCID : Osman Ceng1l 000000020702 6751, Hale Sayan Ozacmak 000000023564 0468, Inc1 Turan 000000032211 3914, Veysel Haktan Ozacmak 0000000326518353

\begin{tabular}{l}
\hline M A K A L E \\
B İ L G I S İ \\
\hline Gönderilme Tarihi: \\
20.07 .2019 \\
Revizyon: \\
28.08 .2019 \\
Kabul: \\
30.08 .2019 \\
\\
Sorumlu Yazar: \\
Hale Sayan Ozacmak \\
hsayan@yahoo.com \\
\hline Anahtar Kelimeler: \\
çevresel zenginleştirme, vasküler \\
demans, BDNF, depresif davranış
\end{tabular}

\section{Ö Z}

Amaç: Bu çalışma çevresel zenginleştirmenin (EE) kronik serebral hipoperfüzyonla (KSH) oluşturulan vasküler demans modelinde depresyon benzeri davranış, serebral korteks ve hipokampüsde beyin kaynaklı nörotrofik faktör (BDNF), kaspaz-1 ve IL-1 $\beta$ seviyeleri üzerine etkisini incelemek için tasarlanmıştır. Daha önceki çalışmalar EE'nin KSH modelinde oksidatif stres inhibisyonu ve endojen nörokoruyucu faktörlerin artırılmasını içeren yararlı etkilere sahip olduğunu göstermişlerdir.

Gereç ve Yöntemler: KSH sıçanlarda bilateral ortak karotid arterlerin oklüzyonu ile oluşturulmuştur. Hayvanlar 3 gruba ayrılmıştır: Sham, standart kafes koşulları ve 4 hafta boyunca zenginleştirilmiş koşullara maruz bırakılan grup. Sükroz tercih testi ve zorlu yüzme testi (FST) KSH sonrası depresif davranışı değerlendirmek için kullanılmıştır. BDNF, IL-1 $\beta$ ve kaspaz-1 düzeylerindeki değişim incelenmiştir.

Bulgular: KSH, hipokampüsde BDNF seviyesinde azalmaya, IL-1 $\beta$ ve kaspaz-1 düzeylerinde artış ile birlikte depresyon benzeri davranışa neden olmuştur..

Sonuç: EE serebral hipoperfüzyon durumunda inflamatuar yanıtı azaltarak ve BDNF seviyelerini koruyarak depresif davranışı iyileştirmede farmakolojik olmayan yeni bir strateji olabilir. 


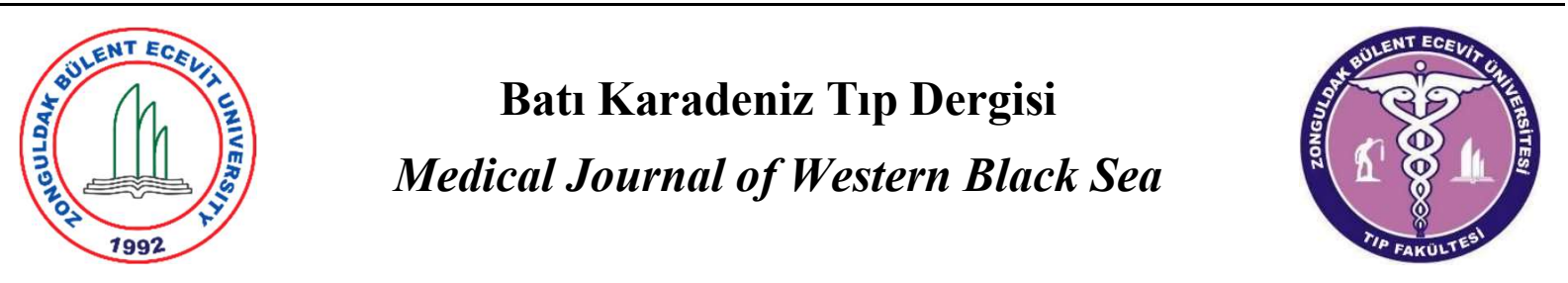

Research Article

Doi: $10.29058 /$ mjwbs.2019.2.2

\title{
Effect Of Environmental Enrichment On Depression-Like Behavior, Cortıcal And Hippocampal BDNF And IL-1 $\beta$ In Vascular Dementia Model
}

\author{
Osman Ceng1l a, Hale Sayan Ozacmak ${ }^{\text {b }}$, Inc1 Turan ${ }^{\text {b }, ~ V . ~ H a k t a n ~ O z a c m a k ~}{ }^{\text {b }}$ \\ ${ }^{a}$ Zonguldak Bulent Ecevit University Health Science Instute Physiology Department, Zonguldak, Turkey. \\ ${ }^{b}$ Zonguldak Bulent Ecevit University School of Medicine, Physiology Department, Zonguldak, Turkey.
}

\begin{tabular}{l} 
A R T I C L E \\
I N F O R M A T I O N \\
\hline Date of Submission \\
20.07 .2019 \\
Revision: \\
28.08 .2019 \\
Accepted: \\
30.08 .2019 \\
Correspondence Author: \\
Hale Sayan Ozacmak \\
hsayan@yahoo.com \\
\hline Key Words: \\
environmental enrichment, \\
vascular dementia, BDNF, \\
depressive like behaviour
\end{tabular}

\begin{abstract}
A B S T R A C T
Aim: This study was designed to investigate the effects of environmental enrichment (EE) on depressive like-behaviour, and cerebral cortex and hippocampus brain derived neurotrophic factor (BDNF), IL-1 $\beta$ and caspase-1 levels in vascular dementia model induced by chronic cerebral hypoperfusion $(\mathrm{CCH})$. Previous studies demonstrated that EE posesses beneficial effects againts $\mathrm{CCH}$ including inhibition oxidative stress and stimulation of endogenous neuroprotective factors.

Material and Methods: $\mathrm{CCH}$ was induced by permanent occlusion of the bilateral common carotid arteries in rats. Animals were divided into three groups: Sham control, standart cage condition and enriched condition for 4 weeks. Sucrose preference and forced swiming test (FST) were used for evaluation of depressive like behaviour after induction of $\mathrm{CCH}$. The change in BDNF, IL-1 $\beta$ and caspase-1 levels were also examined.

Results: $\mathrm{CCH}$ caused a decrease in the hippocampus BDNF level and depressive behaviour associated with increase in IL-1 $\beta$ and caspase-1 levels. EE attenuated depressive behaviour by preserving BDNF level and reducing inflammatory response in hippocampus.

Conclusion: In conclusion, EE may be a new non-pharmacological strategy for ameliorating depressive like behaviour through reducing inflammatory response and restore BDNF levels in cerebral hypoperfusion condition.
\end{abstract}


Giriş

Önceki çalışmalar, kronik serebral hipoperfüzyonun (KSH), beyinde serbest oksijen radikallerinin (OFR) üretilmesi, glial hücrelerin aktivasyonu ve proinflamatuar sitokin yapımının artmas1 yoluyla oksidatif stres ve inflamatuar reaksiyonu tetiklediğini göstermiştir (1-4).

Glial hücrelerin aktivasyonu beyindeki proinflamatuar sitokinlerin ana kaynağını oluşturur. Proinflamatuar sitokinler KSH sonrası çeştili etkilerle nöronal hasara aracılık ederler. Örneğin IL$1 \beta$ oligodentrosit apoptozisine neden olarak KSH sonrası beyaz cevher hasarına yol açmaktadır $(5,6)$. OFR mikroglia ve astrositlerde proinflamatuar gen yapımını artırarak inflamatuar cevabın artışında rol oynar (7). Oksitafif stres ve inflamatuar sitokinlerin artışı ile hipokampal nöronal hasarın gerçekleşmesi kognitif fonksiyonlarda bozulma ile sonuçlanır (8). Nöroinflamasyon ve oksidatif stres vasküler demansın (VD) gelişimi ve ilerlemesinde temel mekanizmaları oluşturur $(1,2,5)$. $\mathrm{Bu}$ nedenle oksidatif hasarın ve nöroinflamatuar olayların inhibisyonu vasküler yetmezlikle ortaya çıkan nöronal hasarın engellenmesinde etkili bir yol olarak görülmektedir.

Vasküler depresyon modeline göre yaşlılarda serebrovasküler patofizyoloji ve depresyon arasında bir ilişki olduğu öne sürülmektedir. Depresyon benzeri davranışın KSH sonrası sıçanlarda gözlendiği saptanmıştır (9). Aynı zamanda inmenin en s1k olarak gözlenen psikolojik sonucu depresyondur. Insanlarda ve deney hayvanlarında inme sonrası depresyonun inflamatuar mediatörlerlerin artışıyla ilişkili olduğu belirtilmektedir (10-12). Serebral iskemi sonrasında OFR artışının depresif semptomların gelişiminde rol

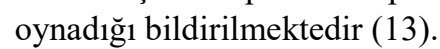

Çevre koşulları gelişim, davranış ve plastisite üzerine güçlü uyarıcı etkiye sahiptir $(14,15)$ Daha önce yapılan çalışmalar deney hayvanlarında çevresel zenginleştirmenin (EE) somatosensoriyel, motor ve sosyal etkileşimin artışı ile kognitif fonksiyonların iyileştirilmesinde etkili olduğu gösterilmiştir. EE hipokampüsde hücresel, moleküler ve davranışsal olarak plastik değişiklikleri artırmaktadır $(14,16)$. Bu etkilerinin yanısıra sıçanlarda EE'nin stres cevabını etkilediği, depresyon ve anksiyete benzeri davranışı azaltabildiği saptanmıştır $(17,18)$. KSH uygulanan sıçanlarda EE'nin oligondendrosit kaybı, beyaz cevher hasarı (19) ve oksidatif stresi (2) azaltmada etkili olduğu görülmüştür.
Beyinden kaynaklanan nörotrofik faktör (BDNF) özellikle korteks ve hipokampüsde sentezlenen sinir büyüme faktörü ailesinin bir üyesidir. BDNF gelişme döneminde, nörogenez, rejenerasyon ve nöral plastisitede nöronların yaşayabilirliğini artırmaktadır $(11,20)$. Bu etkilerinin yanısıra BDNF seviyesinin azalmasının depresyon ile ilişkili olduğu (21) ve BDNF seviyesinin artırılmasının antidepresan etkili olduğu gösterilmiştir (22). Serebral iskemi ve KSH sonrası beyinde BDNF yapımı azalmasının kognitif fonksiyon bozuklukları, yapısal değişiklikler (23) ve depresif davranış (24) ile ilişkili olduğu bildirilmektedir. EE uygulaması BDNF aracılığı ile hipokampal nörogenezi artırmada etkili olabilmektedir (25).

$\mathrm{Bu}$ çalışmanın amacı serebral hipoperfüzyon koşullarında EE'nin etkisinin depresyon benzeri davranış, BDNF, IL-1 $\beta$ ve kaspaz-1 düzeylerinin belirlenmesiyle değerlendirmektir.

\section{Gerec ve Yöntemler}

\section{Deney Hayvanlart}

Çalışmamızda Zonguldak Bülent Ecevit Üniversitesi Deneysel Araştırmalar Uygulama ve Araştırma Merkezi'nden temin edilen 7-8 aylık 300350 gr arasında değişen 30 adet erkek Wistar Albino sıçan kullanılmıştır. Deneyler 12 saat aydınlık 12 saat karanlık sirkadiyen ritimde, sıcaklığın 20-25 C ve nispi nemin \%50-60 olduğu ortamda tutulmuşlardır. Çalışma Zonguldak Bülent Ecevit Üniversitesi Hayvan Deneyleri Yerel Etik Kurulu'nun 11/02/2015 tarih ve 2015-13-01/07 sayılı kararı ile onay alındıktan sonra gerçekleştirlmiştir. Ayrıca Zonguldak Bülent Ecevit Üniversitesi Bilimsel Araştırma Projeleri Koordinasyon Birimi tarafından 2016-26259946-01 nolu proje ile desteklenmiştir.

\section{Deney Gruplart}

Deney hayvanlarının vücut ağırlıkları eşleştirilerek rastgele olarak üç gruba ayrılmıştır: Grup I (Kontrol Grubu) : Herhangi bir oklüzyon yapilmadan boyun insizyonu yapilan standart tip kafes ortamında barındırılan hayvanlardan oluşan grup (n:10). Grup II, KSH uygulanan gruptur: Çift taraflı karotid arter oklüzyonu yapıldıktan sonra 30 gün boyunca standart tip kafes ortamında barındırılan hayvanlardan oluşan grup (n:10). Grup III, KSH +Çevresel zenginleştirme uygulaması yapılan gruptur: Karotid arterlerin oklüzyonu yapıldıktan sonra 30 gün boyunca çevresel 
zenginleştirilme yapılan kafeslerde barındırılan hayvanlardan oluşan grup (n:10).

\section{Kronik Serebral Hipoperfüzyon Oluşturulması}

KSH sonrası ölüm oranını azaltmak için modifiye KSH modeli uygulanmıştır. Önce tek taraf karotid arter oklüzyonu yapıldıktan bir hafta sonra diğer tarafın oklüzyonu gerçekleştirildi(2). Deney hayvanları genel anestezi (ketamin $70 \mathrm{mg} / \mathrm{kg}$, İp., ve Ksilazin $10 \mathrm{mg} / \mathrm{kg}$, i.p.) altında karotid arterlerin oklüzyonu gerçekleştirilmiştir. Çevresel zenginleştirme protokolü olarak türe özgü farklı renk ve şekildelerde oyuncaklar, tüneller, koşu tekerlekleri, ahşap ve metal merdiven ve platformlar içeren özel tasarlanmış büyük kafesler $(90 \mathrm{~cm}$ uzunluğunda $\times 75 \mathrm{~cm}$ genişliğinde $\times 45 \mathrm{~cm}$ yüksekliğinde) kullanıldı. Nesneler konumları günlük olarak değiştirildi (Resim 1).

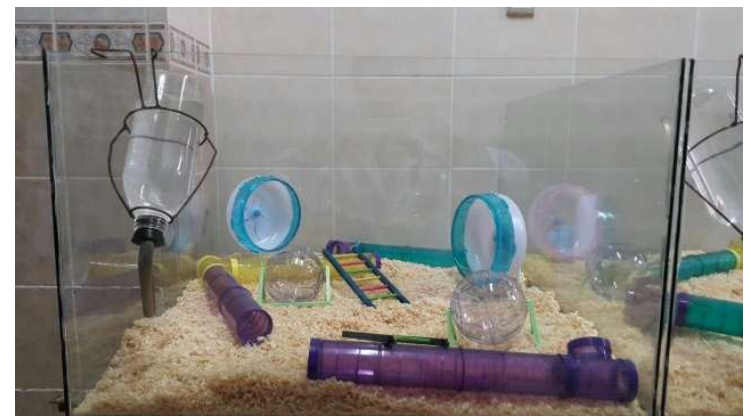

Resim 1. Çevresel zenginleştirme protokününde çeşitli objelerle zenginleştirilen kafes

\section{Davranış Testleri}

Davranış testleri, standart aydınlatma ve sıcaklık kontrollü bir ortamda saat 9:00 ile 16:00 arasında yapild1.

Zorlu Yüzme Tesi (FST) depresyon benzeri davranışı test etmek için sıklıkla kullanılan bir testtir. $\mathrm{Bu}$ modelde su tankı içerisinde platform bulunmayan deney hayvanlarının kaçamayacakları bir ortamda yüzmeye zorlanmasıdır. Testin esası silindirik şeffaf tank içine bırakılan deney hayvanının belli bir süre kaçmak için çaba göstermesi ve daha sonra hareketsiz bir postür sergilemesidir. Teste $45 \mathrm{~cm}$ yükseklik x $20 \mathrm{~cm}$ çapında silindir dayanıklı cam kullanıldı. Tankların $30 \mathrm{~cm}$ 'lik kısmına $22 \pm 1{ }^{\circ} \mathrm{C}$ su dolduruldu. Hayvanlara eğitim vermek ve alıştırmak üzere ilk gün 15 dakikalık bir süre ile hayvanlar yüzmeye tabi tutuldu. İlk oturumdan 24 saat sonra hayvanlar $5 \mathrm{dk}$ boyunca suyun içinde birakıldı. Hayvanların tanktan çıkmak için mücadeleyi bıraktığı ve suyun üzerinde başlarını yukarıda tutarak hareketsiz kaldıkları süre hareketsizlik olarak kabul edilerek not edildi. Hareketsizlik süresi davranışsal çaresizlik olarak değerlendirildi. Hayvan testten sonra sudan çıkarılıp havlu ile kurulanıp sıcak bir ortamda kuruması için bırakıldı (26).

Sükroz tercih testi (STT) deney hayvanlarında anhedoniayı ölçmek için kullanılır. Başlangıçta kafesin sağ ve sol tarafinda 2 farklı su şişesi konuldu. Deney hayvanlarının 24 saat boyunca her iki şişeden de su içmesine izin verildi. 2 gün eğitim yapıldıktan sonra rastgele şişelerden birine \% 2 sukroz içeren su konuldu. Şişeler sıçanlara verilmeden önce ve 24 saat sonra tartıldı. Su ve sukroz tüketimi total tüketim olarak değerlendirildi(27).

Sükroz Tüketimi $=$ Sükroz tüketimi $\times 100 /$ total tüketim

\section{Biyokimyasal Analizler}

Tüm denekler davranış testleri yapıldıktan sonra yüksek doz anestezi (ksilazin+ketamin kombinasyonu) ile feda edilerek buz üstünde hipokampüs ve korteks hızlıca çıkarıldı. Dokular çalışıncaya kadar $-80{ }^{\circ} \mathrm{C}$ 'de derin dondurucuda sakland1.

Doku örnekleri PBS kullanılarak homojenize edildi. Homojenatlar $2-8^{\circ} \mathrm{C}$ 'de 3000 rpm'de 20 dakika santrifüj edilerek süpernatantlar analizlerde kullanıldı. BDNF(Cloud-clone Corp. SEA111Ra), IL-1 $\beta$ (Hazngzhou Eastbiopharm CO. LTD., E2016120203b) ve kaspaz-1 (Bioassay Technology Laboratory E1357Ra) düzeyleri enzyme-linked immün sorbent assay (ELISA) yöntemi ile ticari kit kullanılarak ölçüldü. Sonuçlar standart eğriler kullanılarak ng/ml olarak hesaplandı.

\section{Istatistiksel Analiz}

Verilerin değerlendirilmesi SPSS 22 istatistik paket programı kullanılarak yapıldı. Sayısal değerler ortanca (min-maks) olarak verildi. Gruplar aras1 farklılıkların analizi için Kruskal Wallis testi alt grupların karşılaştırılmaları için ise Dunn testi uygulandı. P'nin $<0.05$ olduğu değerler istatistiksel olarak anlamlı kabul edildi. 


\section{Bulgular}

FST'de hareketsizlik süresinin KSH uygulanan grupta kontrol grubu ve çevresel zenginleştirme uygulanan KSH grubuna göre arttığ gözlendi $(p=0,001)$. Çevresel zenginleştirme ortamına maruz birakılan KSH grubunda depresyon benzeri davranış1 gösteren hareketsizlik süresinin istatistiksel olarak anlamlı azaldığı gözlendi $(p=0,038) \quad$ (Tablo 1)(Şekil 1). STT'de gruplar arasında sükroz tercih etme yüzdesi açısından istatistiksel olarak anlamlı farklılık saptanmadı $(\mathrm{p}=0,212)$ (Tablo 2).

KSH protokolü uygulanan grup ile kontrol grubu karşılaştırıldığında hipokampüsdeki BDNF düzeyleri istatistiksel olarak anlamlı azaldı $(\mathrm{p}=0,001) . \quad \mathrm{KSH}+\mathrm{ÇZ}$ ve $\mathrm{KSH}$ grupları karşılaştırıldığında ise hipokampüsde BDNF düzeyleri arasında istatistiksel olarak anlamlı farklılık vardır $(\mathrm{p}=0,001)$ (Tablo 3)(Şekil 2). Tüm grupların serebral korteksten alınan doku örneklerinde BDNF değerleri açısından istatistiksel olarak anlamlı farklılık gözlenmedi $(\mathrm{p}=0,200)$ (Tablo 3).

Hipokampüsdeki IL-1 $\beta$ düzeyleri, KSH grubu ile kontrol grubu karşılaştırıldığında istatistiksel olarak anlamlı arttığ zenginleştirme(ÇZ) uygulaması IL-1 $\beta$ düzeylerini azaltmada etkili oldu $(\mathrm{p}=0,032)$ (Tablo 3)(Şekil 3). Tüm grupların korteksten alınan doku örneklerinde IL-1 $\beta$ değerleri açısından istatistiksel olarak anlamlı farklılık gözlenmedi $(\mathrm{p}=0,164)$ (Tablo 3$)$.

Hipokampüsdeki kaspaz-1 düzeylerinin, KSH grubu ile kontrol grubu karşılaştırıldığında istatistiksel olarak anlamlı arttığ 1 tespit edildi $(\mathrm{p}=0,020)$. KSH+ÇZ grubu ile $\mathrm{KSH}$ grubu karşılaştığında ise hipokampüsteki kaspaz-1 düzeylerindeki azalmanın istatistiksel olarak anlamlı olduğu belirlendi ( $\mathrm{p}=0,044)$ (Tablo 3)(Şekil 4). Tüm grupların korteksten alınan doku örneklerinde kaspaz-1 değerleri açısından istatistiksel olarak anlamlı farklılık gözlenmedi $(\mathrm{p}=0,199)$ (Tablo 3).

Tablo 1. Zorunlu Yüzdürme Testi (FST) hareketsizlik süresi (sn) gruplar arası karşılaştırılması

\begin{tabular}{|c|c|c|c|c|}
\hline & $\begin{array}{l}\text { Kontrol } \\
(n=10)\end{array}$ & $\begin{array}{c}\text { KSH } \\
(n=10)\end{array}$ & $\begin{array}{c}\mathrm{KSH}+\mathrm{ÇZ} \\
(\mathbf{n}=\mathbf{1 0})\end{array}$ & $\mathbf{p}$ \\
\hline $\begin{array}{l}\text { Hareketsizlik } \\
\text { Süresi (sn) }\end{array}$ & $\begin{array}{c}2 \\
(1-4)\end{array}$ & $\begin{array}{c}33,5 * \\
(22-40)\end{array}$ & $\begin{array}{l}17,5 \text { *\# } \\
(10-24)\end{array}$ & $\mathbf{0 , 0 0 1}$ \\
\hline
\end{tabular}

Değerler ortanca (min-maks) olarak verilmiştir. * Kontrol grubuna göre, \# KSH grubuna göre.

Tablo 2. Sükroz Tercih Testi (SST) gruplar arası karşılaştırılması

\begin{tabular}{|c|c|c|c|c|} 
& $\begin{array}{c}\text { Kontrol } \\
(\mathbf{n = 1 0})\end{array}$ & $\begin{array}{c}\text { KSH } \\
(\mathbf{n = 1 0})\end{array}$ & $\begin{array}{c}\text { KSH+ÇZ } \\
(\mathbf{n}=\mathbf{1 0})\end{array}$ & $\mathbf{p}$ \\
\hline STT (\%) & $\begin{array}{c}72,5 \\
(60-80)\end{array}$ & $\begin{array}{c}63,5 \\
(61-78)\end{array}$ & $\begin{array}{c}71,5 \\
(63-78)\end{array}$ & 0,212 \\
\hline
\end{tabular}

Değerler ortanca (min-maks) olarak verilmiştir

Tablo 3. Hipokampüs ve Korteks'te BDNF, IL-1 $\beta$ ve Kaspaz-1 gruplar arası karşılaştırılması

\begin{tabular}{|c|c|c|c|c|}
\hline & $\begin{array}{c}\text { Kontrol } \\
(n=10)\end{array}$ & $\begin{array}{c}\text { KSH } \\
(n=10)\end{array}$ & $\begin{array}{c}\mathrm{KSH}+\mathbf{C} \mathbf{Z} \\
(\mathrm{n}=\mathbf{1 0})\end{array}$ & p \\
\hline $\begin{array}{c}\text { BDNF } \\
\text { (Hipokampüs) }\end{array}$ & $\begin{array}{c}3,04 \\
(2,85-3,33)\end{array}$ & $\begin{array}{c}2,37 * \\
(1,99-2,61)\end{array}$ & $\begin{array}{c}2,99{ }^{\#} \\
(2,89-3,28)\end{array}$ & 0,001 \\
\hline $\begin{array}{c}\text { BDNF } \\
\text { (Korteks) }\end{array}$ & $\begin{array}{c}1,95 \\
(1,90-2,02)\end{array}$ & $\begin{array}{c}1,89 \\
(1,80-2)\end{array}$ & $\begin{array}{c}1,92 \\
(1,82-2,12)\end{array}$ & 0,200 \\
\hline $\begin{array}{c}\text { IL-1 } \beta \\
\text { (Hipokampüs) }\end{array}$ & $\begin{array}{c}965 \\
(890-1100)\end{array}$ & $\begin{array}{c}1320 * \\
(1100-1455)\end{array}$ & $\begin{array}{c}1134^{\#} \\
(910-1199)\end{array}$ & 0,001 \\
\hline $\begin{array}{c}\text { IL-1 } \beta \\
\text { (Korteks) }\end{array}$ & $\begin{array}{c}1145 \\
(980-1277)\end{array}$ & $\begin{array}{c}1219 \\
(1080-1310)\end{array}$ & $\begin{array}{c}1138 \\
(1010-1300)\end{array}$ & 0,164 \\
\hline $\begin{array}{c}\text { Kaspaz-1 } \\
\text { (Hipokampüs) }\end{array}$ & $\begin{array}{c}2,10 \\
(1,98-2,79)\end{array}$ & $\begin{array}{c}2,60 * \\
(2.10-3,13)\end{array}$ & $\begin{array}{c}2,11 \\
(1,99-2,60)\end{array}$ & $\mathbf{0 , 0 1 2}$ \\
\hline $\begin{array}{l}\text { Kaspaz-1 } \\
\text { (Korteks) }\end{array}$ & $\begin{array}{c}2,43 \\
(2,13-2,62)\end{array}$ & $\begin{array}{c}2,59 \\
(2,14-2,79)\end{array}$ & $\begin{array}{c}2,57 \\
(2,26-2,99)\end{array}$ & 0,199 \\
\hline
\end{tabular}

Değerler ortanca (min-maks) olarak verilmiştir. KSH: Kronik serebral hipoperfüzyon, ÇZ: Çevresel zenginleştirme. * Kontrol grubuna göre. \# KSH grubuna göre 


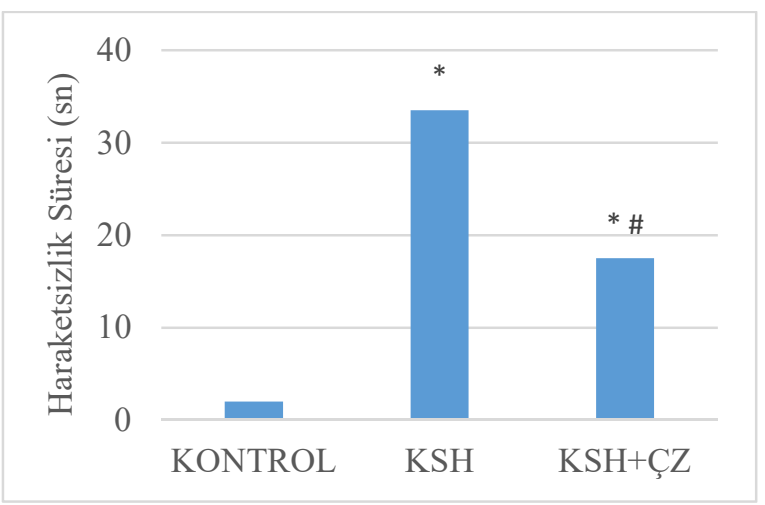

Şekil 1. Zorunlu yüzme testi(FST) hareketsizlik süreleri

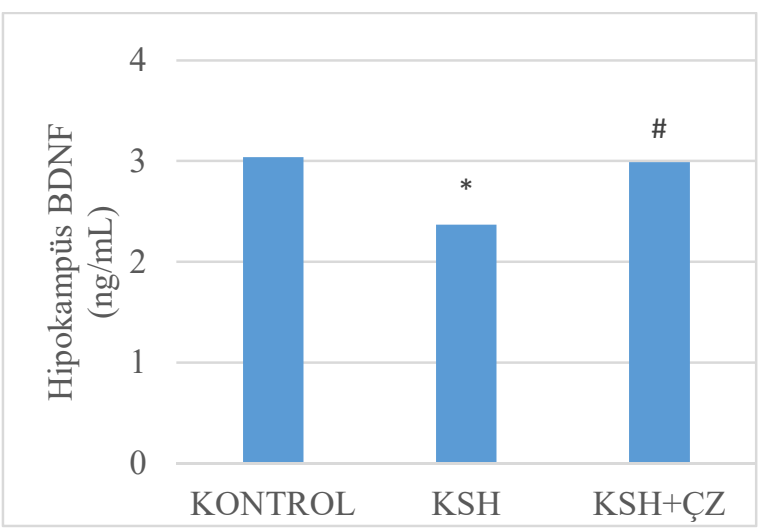

Şekil 2. Tüm gruplara ait hipokampal alandaki $\mathrm{BDNF}$ (ng/ml yaş doku) düzeyleri

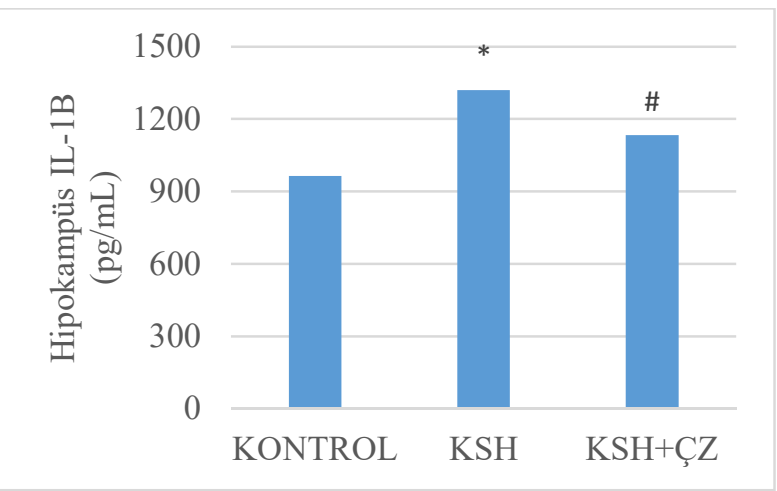

Şekil 3. Tüm gruplara ait hipokampal alandaki IL-1 $\beta$ ( $\mathrm{pg} / \mathrm{ml}$ yaş doku) düzeyleri

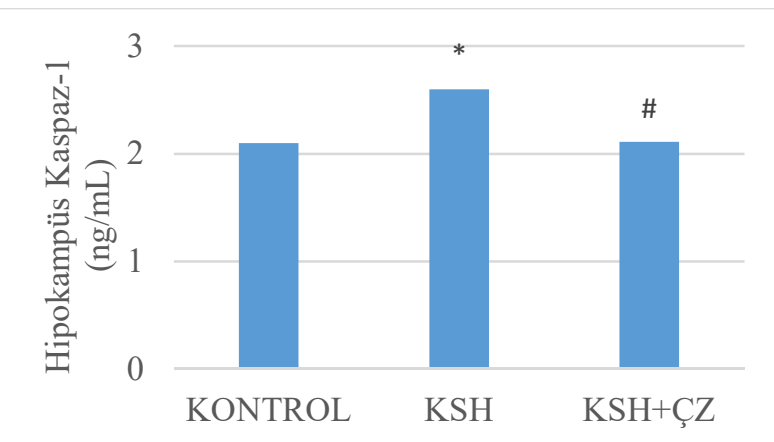

Şekil 4. Tüm gruplara ait hipokampüs kaspaz-1 (ng/ml yaş doku) düzeyleri.

\section{Tartışma}

Çalışmamızdan elde edilen veriler sonucunda KSH'nın hipokampüsde IL-1 $\beta$ ve kaspaz-1 düzeylerinde artış ve birlikte zorlu yüzme testinde immobilite süresinde artış ile karakterize olan depresyon benzeri davranışa neden olduğu saptanmıştır. Çevresel zenginleştirme ile depresyon benzeri davranışın azalması ile birlikte hipokampal alanda BDNF düzeylerinde artış ve IL-1 $\beta$ ve kaspaz1 seviyelerinde azalma eşlik etmiştir.

Yaşlanma, inme sonrası ve Alzheimer hastalığı (AH) gibi çeşitli durumlarda kronik serebral hipoperfüzyon gözlenmektedir ve bu durum kognitif fonksiyon bozukluklarına neden olur. VD, Alzheimer hastalığının ardından ikinci en sık görülen demans tipidir. VD gelişimi hipoksi, iskemi ve hemorajik beyin hasarı ve kardiyovasküler hastalıklarla tetiklenmektedir. İki karotid arter oklüzyonu (2VO) metodu serebral kan akımında önemli ölçüde azalmaya neden olarak VD'ın deneysel modeli olarak kabul görmektedir $(2,28)$. Uzun süreli kan akımında azalma SOR üretimi, nöroinflamasyon, mitokondriyal disfonksiyon, nöronal apoptoz, sinaptik disfonksiyon, nörotrofik faktörlerde azalma, beyaz cevher hasarı, $A \beta$ birikimi ve tau hiperfosforilasyonunu içeren patolojik değişikliklerle sonuçlanır (28-30).

Depresyon geriatrik popülasyonda en sik karşılaşılan problemlerden biridir. Yaşlılıkda gözlenen depresyon ve vasküler patofizyoloji arasında ilişki olduğu ileri sürülmektedir. $\mathrm{Bu}$ nedenle vasküler depresyon hipotezi önerilmiştir. Yaşlı bireylerde gözlenen depresyon semptomlarının serebrovasküler hastalık, koroner arter hastalığı ve aorta aterosklerozu ile ilişkili olduğu ortaya konmuştur $(31,32)$. 2VO sonrasında serebral kan akımı aniden düşer daha sonra yavaş olarak toparlanır. Böylece hipoperfüzyonun ilk aylarında bu hayvanlarda davranış değişiklikleri gelişebileceği düşünülmektedir (9).

Çevresel zenginleştirme kafes içinde farklı alanlara değişik şekil ve büyüklükte objelerin yerleştirilmesi ile oluşturulan sosyal ve fiziksel uyaranları içeren bir uygulamadır. Deney hayvanlarında standart çevre koşullarına göre çevresel zenginleştirmenin duygu, motor fonksiyon, öğrenme ve hafıza gibi nöronal plastisitenin artması ile ilişkili davranışların geliştirilmesinde etkili olduğu nörodejeneratif hastalık modellerini de içeren çeşitli çalışmalarla ortaya konmuştur. Çeşitli çalışmalarda hipokampal nörogenezin ve dendritik büyümenin artırılması, çevresel zenginleştirme 
aracılığla sağlanan kognitif ve motor fonksiyonların gelişiminde rol oynayan bir mekanizma olduğu ileri sürülmüştür (33). KSH sonrasında beyin BDNF düzeylerinin ve öğrenme-hafiza performansının azaldığ $\breve{1}_{1}$ ve bu değişikliklerin çevresel zenginleştirme ile önlenebildiği gösterilmiştir (23).

Deney hayvanlarında depresyon benzeri davranışı test etmek için farklı davranış testleri kullanılmaktadır. Bunların içinde ödül temelli test olan sükroz tercih testi ve umutsuzluk temelli test olan FST yer almaktadır (34). Sükroz tercih testinde azalmış sükroz tercihi depresyon modelinde anhedonia olarak yorumlanır. Çalışmamızda 2VO yapılan sıçanlarda sükroz tercihininde azalmanın olmasını beklenmiştir. Ancak sükroz tercih testinde gruplar arasında istatistiksel olarak anlamlı bir farklılık gözlenmemiştir. Lee ve arkadaşları (2014) KSH oluşturulan sıçanlarda sükroz tercihinin erken dönemde gözlenmediğini ve hipoperfüzyondan 3 ve 6 ay sonra tercihin arttığını bulmuşlardır. Bu artışın yeme davranışından temel sorumlu alan olan hipotalamusdaki kan akımının azalmasına bağlı yeme davranışı değişikliği ile oluşabileceğini bildirmişlerdir(9).

Depresyonla ilişkili olarak hipokampal alanda BDNF miktarı da değerlendirilmiştir. Hipokampüs öğrenme ve hafiza ile ilişkili bir alan olmakla beraber bu limbik yapının depresif ruh hali modülasyonunda, bilgi işlemede ve depresif davranışın oluşturulmasında rol oynadığı giderek daha belirgin hale gelmiştir (35). Depresyonda IL-1 $\beta$ gibi proinflamatuar sitokinlerin artışının yanı sıra BDNF düzeylerinde azalmanın olduğu da bildirilmiştir (36). Nörotrofin hipotezine göre hipokampüs, amigdala ve prefrontal korteksde BDNF'nin azaldığı ve bunun da nöronal apoptoz ve depresyona neden olduğu öne sürülmüştür (37). Depresyonda BDNF düzeyleri ve BDNF reseptör sayısının azaldığı kanıtlanmıştır (38). BDNF reseptörüne bağlanarak nöronların yaşaması ve farklılaşmasına etki eder. IL-1 $\beta$ uygulaması ile oluşturulan depresyon modelinde beyinde BDNF miktarında azalma saptanmıştır (39). KSH'nın beyin hipokampal alanda BDNF seviyelerinde azalmaya neden olduğu gösterilmiştir (40). Çalışmamızda KSH sonrasında hipokampal alanda BDNF seviyelerinde azalmanın olduğu ve çevresel zenginleştirme ile bu azalmanın korunduğu gözlenmiştir. Çalışmamızda KSH yapılan grupta, BDNF seviyesinde azalma ve FST'de immobilite zamanında artış olduğu gözlenmiştir. Elde edilen bu bulgular Sun ve arkadaşlarının (2010) yaptığı çalışmalarındaki çevresel zenginleştirmenin $\mathrm{KSH}$ sonrası BDNF seviyelerini artırması ile benzerlik göstermiştir (23). Çevresel zenginleştirmenin depresif davranışı azaltıcı etki mekanizması tam olarak aydınlatılamamıştır. Shen ve arkadaşları (2019) çevresel zenginleştirmenin depresif davranış1 azaltıcı etkisinin dendritik dallanmalar, sinaptik plastisitede rol oynayan sinaptik proteinlerin ve BDNF yapımını etkileyerek ortaya çıkardığını bildirmektedirler (41). Bizim çalışmamızda KSH uygulanan grupta hipokampal alanda çevresel zenginleştirme ile BDNF seviyelerinin korunmasının depresif davranışı azaltmada etkili olduğunu düşünmekteyiz.

Daha önceki çalışmalar KSH'nın inflamatuar glial hücre aktivasyonuna neden olarak çeşitli inflamatuar reaksiyonlara ve sonuçta kognitif fonksiyon bozuklularına neden olduğunu gösterilmiştir(8,28). KSH ile oluşan hasarda aktive olan mikroglia ve astrositler, sentezlenen ve salgılanan çeşitli kemokinler, sitokinler ve diğer diğer mediatörler önemli rol oynar. $\mathrm{KSH}$ sonras1 beyin dokusunda IL-1 $\beta$, IL-6, TNF- $\alpha$ gibi proinflamatuar sitokin miktarının arttığ bulunmuştur $(4,29)$. Beyinde ortaya çıkan inflamatuar cevap yabancı maddelerin ve yaşlı hücrelerin ortamdan kaldırılması için gerekli olmasına karşın uzun süreli olması durumunda nöron ve sinaps için zararlı etkiler gösterir ve sonuçta beyaz cevher hasarı, nörodejenerasyon ve kognitif bozukluklara neden olmaktadır $(42,43)$. Çalışmamızda daha önceki çalışmaların sonuçlarına benzer şekilde (44) KSH sonrasında hipokampal alanda IL-1 $\beta$ ve kaspaz-1 seviyelerinde artış olduğunu saptadık. IL-1 $\beta$ mikroglia, astrosit, endotel hücreleri, nöron ve dokuya gelen lökositler tarafindan $31 \mathrm{kDa}$ ağırlığında biyolojik olarak inaktif pro-IL-1 $\beta$ olarak sentezlenmektedir. Pro-IL-1 $\beta$ olarak kaspaz-1 ile (IL-1 $\beta$ converting enzyme, ICE) $17 \mathrm{kDa}$ ağırlığında biyolojik olarak aktif IL-1 $\beta$ 'ya dönüştürülür. Kaspaz-1 aktivitesinin kontrolü bu proinflamatuar sitokinin sentezi için hız sınırlayıcı basamağı oluşturur. Çeşitli nörodejeneratif hastalıklarda beyinde IL-1 $\beta$ seviyesinin artışının nörodejenerasyonla ilişkili olduğu ortaya konmuştur. Sitokinler bir döngü içinde daha fazla astrosit ve mikroglial hücreyi aktive ederek daha fazla inflamatuar molekülün sentezine neden olur. Ayrıca sentezlenen inflamatuar moleküller monosit ve lenfositlerin beyine göçüne neden olarak nöroinflamasyonun artışına katkıda bulunurlar (45). Son zamanlarda yapılan deneysel çalışmalarla depresyon benzeri davranış ve proinflamatuar sitokinler arasında bir bağlantı olduğu, IL-1 $\beta$ 'nın depresyon oluşturulan sıçanların beyinlerinde arttığ ortaya konmuştur $(46,47)$. Bu bulgulara benzer sonuçlar insan çalışmalarında da gösterilmiştir ve depresyon teşhisi konan hastaların plazma ve 
postmortem bazı beyin alanlarında proinflamatuar sitokinlerin miktarının arttığı saptanmıştır (47). Bu çalışmada KSH yapılan sıçanların hipokampal alanlarında IL-1 $\beta$ ve kaspaz-1 seviyesinde artışın olduğu ve bununda FST testinde immobilite süresinde artma ile ilişkili olduğu gözlenmiştir. $\mathrm{Bu}$ sonuçlar KSH'nın hipokampal alanda IL-1 $\beta$ ve kaspaz-1 seviyesini artırarak depresyon benzeri davranışın oluşumunda etkili olduğunu göstermektedir. Çevresel zenginleştirme uygulanan grupta FST' de depresyon benzeri davranışın azaldığı ve hipokampal alanda IL-1 $\beta$ ve kaspaz-1 düzeylerinin azaldığı tespit edilmiştir. Bu bulgular çevresel zenginleştirme ile hipokampal alanda inflamatuar cevabın azaltılması depresif davranışı engellemede etkili bir faktör olduğunu düşündürmektedir.

Hipokampüs pek çok majör nöropsikiyatrik hastalıkta önemli rol oynar. KSH ile beyinde oluşan patolojik değişiklik çoğunlukla hipokampüsde gözlenmektedir. Hipokampal alanda sinaptik kayıp ve hacim azalması depresyonda gözlenen bir durumdur (48). Çalışmamız sonucunda hipokampal alanda BDNF düzeylerinin azalması ile birlikte IL$1 \beta$ ve kaspaz-1 seviyelerindeki artışın KSH sonrası gelişen depresif davranışın gelişiminde etkili olabildiği görülmektedir. Çünkü CA1 alanı stres ve hasara son derece duyarlıdır ve bu alanın hacim ve fonksiyonu BDNF ile etkilenmektedir. BDNF depresyonla yakından ilgili olan ruh durumu ve nöronal fonksiyonların korunmasında kritik etkiye sahiptir (49). Proinflamatuar faktörler de sinaptik plastisite ve dendritik dallanmayı değiştirerek nörogenezisi azaltıcı ve nöronal fonksiyon ve yapıda sınırlayıcı etkilere sahiptirler. Çalışmamız sonrasında elde edilen sonuçlara göre çevresel zenginleştirme depresyonla yakından ilişkili olan hipokampal alanda BDNF düzeylerinin korunması ve inflamatuar sitokin yapımının azaltılması yoluyla antidepresan etki gösterdiğini söyleyebiliriz.

\section{Kaynaklar}

1. Kasparová S. et all. Study of the oxidative stress in a rat model of chronic brain hypoperfusion. Neurochem Int. 2005; 46(8):601-11.

2. Cechetti F, Pagnussat AS, Worm PV, Elsner VR, Ben J, da Costa MS, Mestriner R, Weis SN, Netto CA. Chronic brain hypoperfusion causes early glial activation and neuronal death, and subsequent longterm memory impairment. Brain Res Bull. 2012; 87(1):109-16.
3. Saggu R. et all. Astroglial NF-kB contributes to white matter damage and cognitive impairment in a mouse model of vascular dementia. Acta Neuropathol Commun. 2016; 4(1):76.

4. Ozacmak H.S., Ozacmak V.H. and Turan I. Ethyl pyruvate prevents from chronic cerebral hypoperfusion via preserving cognitive function and decreasing oxidative stress, caspase 3 activation and IL-1 $\beta$ level. Bratisl Lek Listy. 2018;119(8):469-475.

5. Kim J.H. et all. Astrocyte-derived lipocalin-2 mediates hippocampal damage and cognitive deficits in experimental models of vascular dementia. Glia. 2017; 65(9):1471-1490.

6. He X.L. et all. Chrysin improves cognitive deficits and brain damage induced by chronic cerebral hypoperfusion in rats. Eur J Pharmacol. 2012; 680(13):41-8.

7. Fu X. et all. Protective role of luteolin against cognitive dysfunction induced by chronic cerebral hypoperfusion in rats. Pharmacol Biochem Behav. 2014; 126:122-30.

8. Hei Y. et all. HMGB1 Neutralization Attenuates Hippocampal Neuronal Death and Cognitive Impairment in Rats with Chronic Cerebral Hypoperfusion via Suppressing Inflammatory Responses and Oxidative Stress. Neuroscience 2018; 383:150-159.

9. Lee S.R. et all. Depressive-like behaviors in a rat model of chronic cerebral hypoperfusion. Transl Stroke Res. 2015; 6(3):207-14.

10. Valkanova V and Ebmeier K.P. Vascular risk factors and depression in later life: a systematic review and meta-analysis. Biol Psychiatry. 2013; 73(5):406-13.

11. O'Keefe L.M., et all. Social isolation after stroke leads to depressive-like behavior and decreased BDNF levels in mice. Behav Brain Res. 2014; 260:162-70.

12. Zhou X.Y., et all. Depression can be prevented by astaxanthin through inhibition of hippocampal inflammation in diabetic mice. Brain Res. 2017; 1657:262-268.

13. Nabavi S.F., et all. Oxidative stress and poststroke depression: possible therapeutic role of polyphenols? Curr Med Chem. 2015;22(3):343-51. 
14. Ramírez-Rodríguez G., et all. Environmental enrichment induces neuroplastic changes in middle age female Balb/c mice and increases the hippocampal levels of BDNF, p-Akt and pMAPK1/2. Neurosciencem. 2014; 260:158-70.

15. Dandi E., et all. Beneficial effects of environmental enrichment on behavior, stress reactivity and synaptophysin/BDNF expression in hippocampus following early life stress. Int J Dev Neurosci. 2018; 67: 19-32.

16. Bayat M., et all. Enriched environment improves synaptic plasticity and cognitive deficiency in chronic cerebral hypoperfused rats. Brain Res Bull. 2015 ; 119:34-40.

17. Mahati K., et all. Enriched environment ameliorates depression-induced cognitive deficits and restores abnormal hippocampal synaptic plasticity. Neurobiol Learn Mem. 2016; 134:379-91.

18. Park J.M., et all. The Effect of Long-Term Environmental Enrichment in Chronic Cerebral Hypoperfusion-Induced Memory Impairment in Rats. Biol Res Nurs. 2017; 19(3):278-286.

19. Hase Y., et all. The effects of environmental enrichment on white matter pathology in a mouse model of chronic cerebral hypoperfusion. J Cereb Blood Flow Metab. 2018; 38(1):151-165.

20. Barros W., et all. Can the effects of environmental enrichment modulate BDNF expression in hippocampal plasticity? A systematic review of animal studies. Synapse 2019; 73(8):1-15.

21. Chen H.H., et all. Overexpression of brainderived neurotrophic factor in the hippocampus protects against post-stroke depression. Neural Regen Res. 2015; 10(9):1427-32.

22. Gao L., et all. Folic acid exerts antidepressant effects by upregulating brain-derived neurotrophic factor and glutamate receptor 1 expression in brain. Neuroreport 2017; 28(16):1078-1084.

23. Sun H., et all. Environmental enrichment influences BDNF and NR1 levels in the hippocampus and restores cognitive impairment in chronic cerebral hypoperfused rats. Curr Neurovasc Res. 2010; 7(4):268-80.

24. Ghosal S., et all. Activity-Dependent BrainDerived Neurotrophic Factor Release Is Required for the Rapid Antidepressant Actions of Scopolamine. Biol Psychiatry. 2018; 83(1):29-37.

25. Zhang X.Q., et all. Increased protein expression levels of pCREB, BDNF and SDF-1/CXCR4 in the hippocampus may be associated with enhanced neurogenesis induced by environmental enrichment. Mol Med Rep. 2016; 14(3):2231-7.

26. Nagasawa M., et all. Chronic imipramine treatment differentially alters the brain and plasma amino acid metabolism in Wistar and Wistar Kyoto rats. Eur J Pharmacol. 2015; 762:127-35.

27. Santiago R.M., et all. The nonsteroidal antiinflammatory drug piroxicam reverses the onset of depressive-like behavior in 6-OHDA animal model of Parkinson's disease. Neuroscience. 2015;300:246-53.

28. Farkas E., Luiten P.G. and Bari F. Permanent, bilateral common carotid artery occlusion in the rat: A model for chronic cerebral hypoperfusion-related neurodegenerative diseases. Brain Res Rev. 2007; 54: $162-180$.

29. Farkas E., et all. Experimental cerebral hypoperfusion induces white matter injury and microglial activation in the rat brain. Acta Neuropathol 2004; 108: 57-64.

30. Ozacmak V.H., Sayan-Ozacmak H. and Barut F. Chronic treatment with resveratrol, a natural polyphenol found in grapes, alleviates oxidative stress and apoptotic cell death in ovariectomized female rats subjected to chronic cerebral hypoperfusion. Nutr Neurosci. 2016 May;19(4):17686.

31. Alexopoulos GS. The vascular depression hypothesis: 10 years later. Biol Psychiatry. 2006; 60(12):1304-5.

32. Tiemeier H., et all. Relationship between atherosclerosis and late-life de-pression: the Rotterdam Study. Arch Gen Psychiatry. 2004; 61(4):369-76.

33. Wang H., et all.The activated newborn neurons participate in enriched environment induced improvement of locomotor function in APP/PS1 mice. Brain Behav. 2019; 9:1-8.

34. Anisman H. and Matheson K. Stress, depression, and anhedonia: caveats concerning animal models. Neurosci Biobehav Rev. 2005;29(4-5):525-46. 
35. Tang J., et all. The effects of running exercise on oligodendrocytes in the hippocampus of rats with depression induced by chronic unpredictable stress. Brain Res Bull. 2019; 149:1-10

36. Zhang C., et all. Minocycline ameliorates depressive behaviors and neuro-immune dysfunction induced by chronic unpredictable mild stress in the rat. Behav Brain Res. 2019; 356:348357.

37. Hashimoto K. Brain-derived neurotrophic factor as a biomarker for mood disorders: an historical overview and future directions. Psychiatry Clin. Neurosci. 2010; 64: 341-357.

38. Wook Koo J., et all. Essential role of mesolimbic brain-derived neurotrophic factor in chronic social stress-induced depressive behaviors. Biol. Psychiatry. 2016; 80: 469-478.

39. Zhang Y.P., et all. Mifepristone attenuates depression-like changes induced by chronic central administration of interleukin-1 $\beta$ in rats. Behav Brain Res. 2018; 347:436-445.

40. Magami S., et all. The Effects of Astrocyte and Oligodendrocyte Lineage Cell Interaction on White Matter Injury under Chronic Cerebral Hypoperfusion. Neuroscience. 2019; 406:167-175.

41. Shen J., et all. The enriched environment ameliorates chronic unpredictable mild stressinduced depressive-like behaviors and cognitive impairment by activating the SIRT1/miR-134 signaling pathway in hippocampus. J Affect Disord. 2019; 248: 81-90.

42. Zhou Y., Zhang J. and Wang L. Interleukin-1beta impedes oligodendrocyte progenitor cell recruitment and white matter repair following chronic cerebral hypoperfusion. Brain Behav Immun. 2017; 60: 93105.

43. Ransohoff RM. How neuroinflammation contributes to neurodegeneration. Science 2016; 353: 777-783.

44. Wang Q.G., et all. Angiotensin IV suppresses inflammation in the brains of rats with chronic cerebral hypoperfusion. J Renin Angiotensin Aldosterone Syst. 2018; 19(3):1-7.

45. Shaftel S.S., Griffin W.S. and O'Banion M.K. The role of interleukin-1 in neuroinflammation and
Alzheimer disease: an evolving perspective. J Neuroinflammation 2008; 5:1-12.

46. Fernandes J.and Gupta G.L. N-acetylcysteine attenuates neuroinflammation associated depressive behavior induced by chronic unpredictable mild stress in rat. Behav Brain Res. 2019;364:356-365.

47. Raison C.L., Capuron L. and Miller A.H. Cytokines sing the blues: inflammation and the pathogenesis of depression. Trends Immunol. 2006; 27(1):24-31.

48. Liu W., et all. The Role of Neural Plasticity in Depression: From Hippocampus to Prefrontal Cortex. Neural Plast. 2017;2017:1-11

49. Hu M.Z., et all. Antidepressant-like effects of paeoniflorin on post-stroke depression in a rat model. Neurol Res. 2019; 41(5):446-455 